\title{
Muslims and Christians Face to Face
}

\section{By Kate Zebiri. Oxford: One World Publications. 258 pp.}

Muslims and Christians Face to Face is an academic research work that observes the various responses of Muslims to Christianity and Christians to Islam. It is written by Kate Zebiri, who is a lecturer in Arabic and Islamic Studies at the School of Oriental and African Studies, University of London.

In the first chapter, "Factors Influencing Muslim-Christian Relations," Zebiri discusses the four factors that affect Muslim and Christian perceptions of each other.

The first factor is what the Qur'an says about Christians and Christianity, and the way in which the Qur'anic material has been interpreted. With regards to this factor the author discusses the Qur'anic awareness of religious plurality, the Qur'anic perception of Jesus, the earthly end of Jesus in the Qur'an, and what the Qur'anic verses say about the salvation of the People of the Book in the hereafter. Moreover, Zebiri tries to draw attention to the difference between what the Qur'an says about Christians and Christianity, and the way in which the Qur'anic material has been interpreted, and the difference between the commentators' and jurists' positions toward Christianity, in both the classic and contemporary periods.

The second factor is the history of Muslim-Christian relations and the affect of historical memory. Here the author describes the relation between the Arab Muslim conquest and the Byzantine Christian Empire; the situation of Christians under Muslim rule; the affect of the Crusades on the Muslims' attitudes to Christianity; the development of the Christian attitude to Islam from ignorance during the European Christendom, to anti-Muslim polemic attitude to conduct studies on Islam based on reliable sources after the Renaissance, to using Islam as a theme in intemal Christian polemic during the time of the Reformation, to admiring Islam for its own sake in the Enlightenment; and finally, the attitude of both liberal and conservative Christians to Islam today.

The third factor is the relationship between Christian missions and imperialism and the influence this has on the Muslim attitude toward Christianity today. With regards to this factor, the author explores the interrelationship between Colonialism and Christian missions, and how it has been implanted in the Muslim consciousness and become part of the anti-Westem discourse.

The fourth factor is Christian and Muslim views on dialogue. In this part the author shows the Christian acknowledgment of Islam as a result of the Christian ecumenical movement. She states that Muslims have been slow to initiate and participate in organized dialogue. In addition, she mentions that many Christians and Muslims see dialogue as antithetical to their mission or da'wah, believing that one compromises the other. 
The second chapter is "Muslim Popular Literature On Christianity." In this chapter the author surveys eighteen books which are available in Western bookshops. Most of this chapter is devoted to the relationship between Christianity and modern Western civilization. However, Zebiri argues the eighteen works' outlooks on the Bible: text and interpretation, the Jesus of the Gospels and the Jesus of the Qur'an, how and why Christian doctrine became corrupted, Christianity and Western civilization, and contemporary Christianity.

Zebiri's observations are based mostly on the methodology the authors of those works followed rather than on the material itself. Zebiri states that those works, in certain areas demonstrate the close relationship between the Islamic apologetic and the anti-Christian polemic. Moreover, their sources are used selectively, in most cases the extreme opinions of Western scholarship are those chosen. Because many of the authors know Urdu and few of them read Arabic, she expects that at least some of them have been exposed to Rahmatullah's Izhar al-Haqq, which, in her opinion preserves much of the medieval material, particularly on the subjects of scriptural falsification, doctrinal material, and prophecies of Muhammad in the Bible.

Despite the fact that many Christians agree with the material which criticizes the weaknesses in the Christian tradition (past and present), the author believes that since this criticism is not addressed to Christians, it is made in a spirit of aggression, and therefore cannot be called destructive. Zebiri's last observation, but not her least important, is that most of the works (having excluded those by Western converts) demonstrate, to a certain extend, the continuity with the concerns and style of the medieval tradition.

In the third chapter, "Protestant Missionary Literature On Islam," Zebiri attempts to illustrate Islam through the perception of Christian missionary literature. Zebiri focuses on several contemporary missionary writers and their approach to Islam. According to Zebiri, the general issues and ideas addressed by missionary literature are the same, emphasizing the consensus among writers in regards to what issues are important, although great divergence in syle are apparent. Zebiri determines that missionary literature on Islam addresses several basic topics: the Qur'an, Muhammad, and the relationship between God and man.

In dealing with the Qur'an, some missionary writers believe it can be used as a bridge to attract converts. Others disagree, arguing that any recognition of the Qur'an will implicitly be disregard of the Bible. The dissenting writers state that if the Qur'an can be interpreted through Christian eyes, this would open the Bible to equal interpretation by Muslims, which is not acceptable in their view. Another issue which arises in regards to the Qur'an is that the revealed nature of the Qur'an cannot be accepted by Christianity. Therefore, some missionaries describe the Qur'an as a compilation influenced by Christian, Jewish, Pagan, and other literature; while others attempt to show flaws in the text. Zebiri points out that many of missionaries who attempt to analyze the Qur'an are not proficient in Arabic and therefore their linguistic critiques of the text cannot be taken seriously. Zebiri also points out that factual errors are presented in a somewhat biased perspective, in regards to how they deviate from the Biblical stories.

The main concern of the missionary literature with Muhammad is regards to prophesy. They cannot accept his prophecy because, in their view, this would disregard the entire purpose of Jesus and his crucifixion. Furthermore, missionary literature attempts to present the Muslims' zeal in regards to the perfection 
of Muhammad's character and their great love for him as a misplaced need for the intermediary role of Jesus.

The third issue addressed repeatedly in missionary literature concerns the nature of the relationship between man and God. The literature projects the idea that the Muslim relationship with God is often lacking and impersonal due to essential differences between the nature of man and the nature of God. In Christianity, because of Jesus's intermediary role, God and his love is more attainable and allows for a closer relationship between man and God. This argument is presented in a method which gives the reader a feeling of favoritism by the author toward the missionary perspective - a contrasting perspective is not presented like in the two previous arguments.

In the fourth chapter, "Study of Christianity by Muslim Intellectuals," Zebiri presents the available Muslim literature on Christianity. From the beginning, Zebiri states that this literature is limited because in recent times there has been no in-depth scholarly work on Christianity by Muslims. The scholars whose ideas are presented can be divided into two main groups according to their position on Islamic matters and, consequently, their perception of Christianity: AlFaruqi and such scholars, who are more rationalistic; and Askari and Arkoun, who are more interested in mysticism and the esoteric essence of religion.

Muslim scholars such as Al-Faruqi, Akhtar, and Izetbegovic believe that Christianity is incongruent with holding power. According to them, passivity is perceived as essential to the Christian faith; political action and social activity are incompatible with Christian philosophy. Their view is that Jesus's message was sent to the individual for self-improvement rather than to society, in contrast to Islam. Therefore, when Christianity does attain power it does not know what to do with it, thus resulting in oppression and intolerance. Therefore, Muslim scholars do not believe Christianity can be a political religion without restructuring its beliefs. Al-Faruqi holds the view that there are two types of Christianity: Western and original. Al-Faruqi's main conclusion is that Christianity deals with love of God while Islam places God's will at the center. Izetbegovic has a somewhat different interpretation af Christianity. He views it as a religion for the more elitist religious zealots with the intention of correcting man internally. Islam in contrast, is a religion for all which must be practiced in the center of everyday life. He summarizes this perspective by saying, "In the Gospels, God is father, in the Qur'an, God is master. In the Gospels, God is loved, in the Qur'an, God is respected" (p. 147). Al-Attas presents a more traditional perspective in confronting Christianity. He believes that it is a distortion of the original message, that Jesus was sent as a messenger to the Jews to reform their ways and not to bring them a new religion. Al-Attas contrasts the contamination of Christianity with the purity of Islam as a preserved religion with fundamental principles and doctrines which cannot be altered or contaminated.

The other stream of Muslim thinking opposes the above perspectives and can be represented by the works of Askari and Arkoun. Their main point is that religion is generally the same but, because of coincidental occurrences, diverged into separate entities. They argue that theological differences are often the result of misunderstood wording, rather then differences in basic doctrinal issues. These authors also propose that the different strategies used by those who brought the religions is a result of the atmosphere they emerged from, and therefore are coincidental not intrinsic.

In regards to doctrine, the most central to Christianity are unacceptable to Muslims. These central doctrines include the Trinity, incarnation, sin, and 
redemption. Throughout the chapter, especially when dealing with al-Faruqui, the author is of the opinion that Muslim scholars' arguments against Christianity are questionable, even from an Islamic point of view.

In respect to their sociopolitical facts, Islam and Christianity diverge. Islam does not separate religion and politics, they are always viewed as a unit. Christianity, however, has a wide array of views on religious aspects in the sociopolitical sphere. Christianity usually does not accept political religion, which Muslim scholars view as a delineation from Jesus' original message, because he faced the political entities of his time.

After presenting the works and ideas of Muslim scholars on Christianity, Zebiri disregards all their views as flawed. For example, Al-Faruqui is criticized for not applying a reciprocal methodology of his study of Christianity. Zebiri also states that different criteria are used by the Muslim scholars on studying the two religions, thus resulting in a biased interpretation. Zebiri also deligitimizes the work of Muslim scholars in using historical-critical methodology by saying it is not equally applied in studying Chrisitanity and Islam.

The fifth chapter, "Approaches to Islam by Christian Islamicists and Theologians," basically talks about how Islam was perceived in the past and how it is now perceived among modern Christian scholars who have a strong grasp of Islamic history and/or Arabic. The author describes how initially Muslims were seen as diabolic, and their faith man-made, or a punishment for Christians. Zebiri claims that today's scholars are growing to understand the teachings of Islam and, thus, have moved to categorize it among the Abrahamic faith. There are no differing degrees of acceptance of Islam by different scholars. For example, Bijlefeld, in his 1959 thesis titled "Islam as Post-Christian Religion" brings up the issue that Muslims see themselves as a continuation of the Jewish and Christian traditions. Many others see Islam as a nature religion and believe that this actually holds Islam in a positive light. Others, however, like Arndlez, argue that Muslim theology does not recognize the concept of natural religion and that the will of God is the only justification for ethical or legal commands. By advocating certain scholars, the author seems to be stressing the importance of disregarding differences among the Western religions and centering on a unifying archetype, such as Abraham.

Muhammad is discussed by comparing the negative portrayals of the last prophet to the more politically correct analysis of him. Modern Christian scholars have chosen to focus on Muhammad's achievements and moral character, as gathered through historical evidence. For example, Watt depicts Muhammad in a favorable light by focusing on his readiness to undergo persecution for his belief, the high moral character of the men who believed and looked up to him as a leader, and the greatness of his ultimate achievement. Zebiri also pinpoints the progression of Muhammad from preacher in Makkah to diplomat, soldier, and politician in Madinah. Some Christians feel that Muhammad could be a prophet, but not one in the same sense as Muslims view him as a prophet. In contrast, many scholars believe Muhammad could not have been a prophet because he bore witness to Christ's second coming, and the final judgment. $\mathrm{He}$ also defined God in negative terms, that is, he described what God is not. $\mathrm{He}$ also described God in positive terms, in the sense that he challenged prevailing human values and introduced social reforms. Also, a positive aspect emphasized in viewing Muhammad is the fact that he lifted Arabs from polytheism to the height of monotheism. 
Zebiri also addresses the ways in which the Qur'an is interpreted by Christians and whether it is characterized as the words of God by these scholars. Scholars such as Bijlefeld and Smith reject the idea of examining the extreme opinions of the Qur'an, that is, as a man-made product or as God's words. They prefer to see the Qur'an simply as sacred-scripture of Muslims.

All the thinkers in this section see Christian scripture or revelation as a combination of human and divine elements. They view the Qur'an in the same way. Zebiri claims that there is an overlap between some Christian views and moderate Muslims views. The changes taking places in Christian study are due to the increased contact with Muslims. Zebiri points out that the main prerequisite for interpretation of the Qur'an is serious scholarly engagement.

Although Zebiri bases her work on a large body of both Islamic and Christian materials and she reviews perceptions of both sides to each other. Whoever reads the book will notice that the material has been selectively chosen to support certain ideas, mainly about Islam, that is well formed in Zebiri mind and perception of Islam. This fact makes clear the author's partiality in performing analyses and drawing conclusions.

Neither Muslims nor Christians disregard the fact that there are many differences between the two religions; moreover, there is nothing new to be discovered in sense of these differences. So this book doesn't add anything new that will narrow the difference or widen the gap between Islam or Christianity. The general spirit among the majority of Muslims and Christians is not to explore the differences between the religions but, on the contrary, to find a common ground from which both can interact and approach each other positively.

Salem A. Salem Student at the School of Islamic and Social Sciences Leesburg, VA 